\title{
EU, MULHER... POR UMA NOVA VISÃO DO MUNDO ${ }^{1}$
}

Paulina Chiziane ${ }^{2}$

Deus disse: "não é bom que o homem esteja só”. Adormeceu-o, tirou uma das suas costelas e transformou-a em mulher. O homem disse: "é o osso dos meus ossos e carne da minha carne". Mas a mulher fez-se parceira da serpente. Tomou a fruta da árvore proibida, comeu-a. Sentindo-a deliciosa deu-a ao homem. Ambos abriram os olhos para o bem e para o mal. Por isso Deus amaldiçoou a mulher e disse: "multiplicarei os tormentos da tua gravidez. Serás governada pelo homem que será teu senhor".

Os problemas da mulher surgem desde o princípio da vida, de acordo com as diversas mitologias sobre a criação do mundo. Na mitologia bantu, depois da criação do homem e da mulher, não houve maldição nem pecado original. Mas foi o homem que surgiu primeiro, ganhando, deste modo, uma posição hierarquicamente superior, que lhe permite ser governador dos destinos da mulher. Isto significa que a difícil situação a mulher foi criada por Deus e aceite pelos homens no princípio do mundo.

As diversas mitologias não são mais do que ideologias ditadas pelo poder sob a máscara da criação divina.

Comparo a mulher à terra porque lá é o centro da vida. Da mulher emana a força mágica da criação. Ela é abrigo no período da gestação. É alimento no princípio de todas as vidas. Ela é prazer, calor, conforto de todos os seres humanos na superfície da terra.

Nas religiões bantu, todos os meios que produzem subsistência, riqueza e conforto como a água, a terra e o gado, são deificados, sacralizados. A mulher, mãe da vida e força da produção da riqueza, é amaldiçoada. Quando uma grande desgraça recai na comunidade sob a forma de seca, epidemias, guerra, as mulheres são severamente punidas e consideradas as maiores infractoras dos princípios religiosos da tribo pelas seguintes razões: são os ventres delas que geram feiticeiros, as prostitutas, os assassinos e os violadores de normas. Porque é o sangue podre das suas menstruações, dos seus abortos, dos seus nado-mortos que infertiliza a terra, polui os rios, afasta as nuvens e causa epidemias, atrai inimigos e todas as catástrofes. 
Em Moçambique, o povo tsonga celebra o mbelele quando a comunidade é afectada por uma grande seca. Antes de decidir a realização do magno ritual, os homens castigam as mulheres. Fazem preces para os deuses do pai e da mãe. Falham. Os reis e os sacerdotes fazem preces aos deuses do clã ou da tribo. Falham. Recorrem de novo à mulher porque reconhecem nela a fertilidade e sobrevivência do mundo. No mbelele, elas correm nuas de baixo do sol revolvendo sepulturas, purificando a terra, gritando, cantando para que as nuvens escutem. Só a nudez da mulher que quebra o silêncio dos deuses e das nuvens porque ela é a mãe do universo.

Nós, mulheres, somos oprimidas pela condição humana do nosso sexo, pelo meio social, pelas idéias fatalistas que regem as áreas mais conservadoras da sociedade. Dentro de mim, qualquer coisa me faz pensar que a nossa sorte seria diferente se Deus fosse mulher.

Mas como é que seria o mundo se Deus fosse mulher? A ordem da vida estaria invertida? As escalas de valores seriam diferentes? A justiça e o amor seriam colocados a favor da promoção da felicidade humana? Nessa sociedade, o que teria mais valor: a vaidade característica da mulher, o dinheiro, ou o talento, a vontade e a força de construir? Qual seria o poder mais forte: o material ou o espiritual? É difícil responder a esta pergunta. Mas tentemos dar voltas à cabeça, imaginemos e busquemos a resposta a esta fantasia na realidade que nos rodeia. Olhemos para o passado e presente. A história humana tem mulheres que atingiram as esferas mais altas da sociedade. Ao longo dos séculos, houve rainhas, imperatrizes, embaixadoras, ministras. A maior parte dessas mulheres revelaram-se mais preparadas para a ganância e para a vaidade. Exprimiram até ao exagero o seu gosto pela grandeza. Nunca usaram o seu poder para melhorarem as condições de vida do seu povo. Ficaram felizes com as suas altas posições e não fizeram nenhuma concessão a favor da mulher. A rainha Cleópatra fornece-nos um bom exemplo. Diz-se que dirigiu o seu país com força de ferro; diz-se ainda que foi uma grande general. Fala-se ainda hoje das suas fraquezas. Preocupou-se muito com s seus vinhos, com as suas pérolas, com a ponta do seu nariz e com a beleza que muito enlouqueceu os generais romanos. Da condição social das mulheres do seu povo, Cleópatra não se lembrou nunca. Em conclusão poderei dizer que são muito poucas as mulheres que, estando no poder, se preocupam com os problemas de outras mulheres.

Se acreditamos na ideia de que o homem é a imagem de Deus, podemos também imaginar que a rainha é a imagem de deusa. Valerá a pena alimentar a ilusão de que o mundo seria diferente e melhor se Deus fosse uma mulher? Penso que não. A história mostra-nos que não basta ser mulher para ser justa. A questão é muito mais profunda.

Estas minhas divagações servem-me apenas de estímulo. Com elas pretendo encontrar a força para enfrentar a dura realidade que me cerca. Sei que devo modificar o ambiente pela força de meu espírito por que 
às preces aos deuses homens e aos deuses mulheres, quer sejam feitas em voz alta ou silenciosa, as únicas respostas que se obtêm são silêncio absoluto. Nesta minha batalha por sobrevivência digna vou ganhando mais luz e mais força. Cada dia cresce a minha experiência e mais claras se tornam minhas reflexões sobre a vida e sobre o mundo. Pretendo revelar um pouco desta experiência sem falsidade nem superficialização, para quebrar o silêncio, para comunicar-me, para apelar à solidariedade e encorajamento das outras mulheres ou homens que acreditam que se pode construir um mundo melhor.

$\mathrm{Na}$ etnia Tsonga (minha etnia) quando uma rapariga nasce, a família e os amigos saúdam a recém-nascida dizendo: hoyo-hoyo mati (bem vindo a água), atinguene tipondo (que entre o dinheiro), hoyo-hoyo tihomo (bem vindo o gado). O nascimento de uma rapariga significa mais uma força de ajuda a transportar água, mais dinheiro ou gado cobrado pelo lobolo.

Na infância a rapariga brinca à mamã ou a cozinheira, imitando as tarefas da mãe. São momentos muito felizes, os mais felizes da vida da mulher tsonga. Mal vê a primeira menstruação é entregue a marido por vezes velho, polígamo e desdentado. À mulher não são permitidos sonhos nem desejos. A única carreira que lhe é destinada é casar e ter filhos.

Foi neste ambiente que eu nasci, numa família de pai, mãe e oito filhos. Pertenço a uma família pequena comparada com as restantes onde havia duas ou mais esposas. Como me tornei escritora? É algo que não sei responder. Apenas posso dizer que a escrita escolheu-me, da mesma forma que a natureza me tornou mulher. Posso confirmar que a minha vivência também contribuiu para conduzir-me a este caminho.

As minhas memórias mais remotas são das noites frias à volta da lareira, ouvindo histórias da avó materna. Nas histórias onde havia mulheres, elas eram de dois tipos: uma com boas qualidades, bondosa, submissa, obediente, não feiticeira. Outra era má, feiticeira, rebelde, desobediente, preguiçosa. A primeira era recompensada com um casamento feliz e cheio de filhos; a última era repudiada pelo marido, ou ficava estéril e solteirona.

Acompanhava todos os passos da minha mãe. No rio, enquanto me banhava, a minha mãe cantava e lavava roupas e mágoas. As outras mulheres faziam o coro. Estas cantigas umas vezes eram suspiros e outras murmúrios de angústia. Já em casa ouvia as cantigas de pilar milho e as de pilar amendoim. Eram todas tristes. O que consegui observar é que os homens ouviam-nas com total indiferença. Em momento nenhum da minha vida me recordo de ter ouvido, da boca de um rapaz ou de um homem, estas cantigas de mulher.

Aos seis anos de idade abandonei o campo com meus pais e fomos viver no subúrbio da cidade. Entrei na escola católica. Apesar das grandes diferenças na educação da casa e da escola, encontrei harmonia na matéria que dizia respeito ao lugar da mulher na vida e no mundo. A educação 
tradicional ensina a mulher a guardar a casa e a guardar-se para pertencer a um só homem. A escola também ensinava a obediência e a submissão e preparava as raparigas para serem boas donas de casa, de acordo com o princípio cristão.

Nas ruas do subúrbio sentia imensas saudades da vida livre e dos passeios nos campos. Para matar a saudade passava o tempo desenhando paisagens na tentativa de restaurar o paraíso perdido da primeira infância. Já adolescente, sonhei em tornar-me pintora. A família disse que não. A escola disse que não. A sociedade também disse que não. Porque não é bom para uma mulher. Porque pintura é arte e o artista é marginal. Eu estava a ser educada para ser uma boa mãe e esposa. Recalcaram o meu sonho e não o fizeram por mal, queriam apenas proteger-me porque se preocupavam com o meu destino. Deixei de pintar paisagens. Nas horas vagas, divertia-me tentando descrever as mesmas paisagens, realizando de forma alternativa o sonho da pintura. Foi assim que penetrei nos caminhos traçados por Deus e pelos homens.

Mas, por outro lado, o livro exercia sobre mim um efeito mágico. Em toda a minha adolescência, viajei pelo mundo do Oeste, idolatrei os heróis como Kit Carson, Búfalo Bill. Foi com a literatura marginal que entrei no mundo da leitura porque o meu meio social não tinha acesso a bibliotecas nem centros de cultura. Só no segundo nível de ensino secundário é que consegui tomar contacto com a verdadeira literatura.

À medida que ia crescendo, ia contemplando os fundamentos da existência humana, cada dia com maior profundidade. Observava o labor dos seres humanos, o seu sacrifício, os homens que morriam sem nunca terem conseguido realizar os seus sonhos. Encontrava uma grande contradição entre o mundo que me rodeava e o mundo que residia no meu íntimo. Senti necessidade de desabafar. Desabafar lavando nas águas do rio, como fazia a minha mãe, já não fazia parte do meu mundo. As cantigas na hora de pilar não eram suficientes para libertar a minha opressão e projectar a beleza do mundo que sonhava construir. Comecei a escrever as minhas reflexões.

Primeiro foram as frases soltas nos cantos dos cadernos. Depois foi o diário. A seguir foram os poemas e as cartas de amor no tempo da primeira paixão. Mais tarde foram textos mais seguros, pequenos contos, pequenas crônicas e o sonho de um dia escrever um livro. Este sonho adormeceu porque me casei e queria ser boa esposa. Mas a vida conjugal deu-me a provar as primeiras amarguras. Minha alma tornou-se uma muralha de solidão e silêncio. Olhei para mim e para outras mulheres. Percorri a trajectória do nosso ser, procurando o erro da nossa existência. Não encontrei nenhum. Reencontrei na escrita o preenchimento do vazio e incompreensão que se erguia à minha volta. A condição social da mulher inspirou-me e tornou-se meu tema. Coloquei no papel a aspirações da mulher no campo afectivo para que o mundo as veja, as conheça e reflita sobre elas. Se as pró- 
prias mulheres não gritam quando algo lhes dá amargura da forma como pensam e sentem, ninguém o fará da forma como elas desejam. Foi assim que surgiu a minha primeira obra, Balada de amor ao Vento, tornando-me deste modo uma das poucas escritoras do meu país.

Como é que a sociedade recebeu a notícia de que eu estava a escrever o meu livro? Primeiro com cepticismo e muito desprezo da parte dos homens. Muitas pessoas acreditavam e ainda acreditam que a mulher não é capaz de escrever mais do que poeminhas de amor e cantigas de embalar. Consideraram-me uma mulher frustrada, desesperada, destituída de razão. Foi um momento terrível para mim. Mas, por outro lado, estas atitudes tiveram um efeito positivo porque forçaram-me a demonstrar pela prática que as mulheres podem escrever e escrever bem. Devo confessar que nas condições da actual sociedade, se a mulher pretende um reconhecimento igual ao do seu parceiro masculino deve trabalhar duas ou três vezes mais. Do período que vai da escrita do livro até a sua publicação, entrei em contacto com homens de diversas instituições e que não me ajudaram em nada ou ajudaram muito pouco. Contudo, quase todos eles não se esqueceram de fazer-me propostas sexuais, convites de jantar, como condição necessária para a ajuda de que tanto necessitava. Mais tarde entrei na Associação dos Escritores. Mesmo ali a minha integração como mulher não se fez sem grandes esforços.

Ainda hoje, a sociedade moderna considera os artistas como seus membros marginais. Ser mulher e ser artista torna-se um verdadeiro escândalo. Escândalo que tive que arriscar e suportar. Nesta sociedade a mulher só pode falar de amor e sexo com outras mulheres e também em segredo. Falar em voz alta é tabu, é imoral, é feio. No meu livro falo da vida, do amor e sexo. Com as minhas mãos accionei uma bomba sobre a minha cabeça. Uma boa parte das pessoas pensa que escrevi o amor porque o pratico em demasia. Outros consideram-me uma pessoa bastante entendida em matéria de amor e sexo e com vontade de contar experiências. As boas pessoas evitam a minha linguagem e o meu contacto que consideram nocivo e comprometedor.

Dois anos depois da publicação desta obra, ainda continuo a receber propostas de homens dos mais diversos quadrantes da esfera social. Querem conhecer-me de perto, apalpar-me, provar-me física e moralmente para entender melhor esta coisa de mulher escritora. Não lhes ligo importância nenhuma. Ignoro-os e continuo o meu caminho. A coisa mais gratificante no meio desta história foi a alegria e carinho com que a camada feminina me recebeu a mim e ao meu livro. Os jovens de ambos os sexos encorajam-me e pedem que escreva mais livros. Alguns até prometem que um dia serão escritores.

Sou mulher comprometida com diversas ocupações. Tenho o emprego, principal fonte de sustento. Tenho a casa e a família. E tenho o sonho da escrita por realizar. O trabalho da escrita é mais árduo e solitário. Para 
escrever é preciso planificar, arquitectar as idéias, investigar, ler e conversar. Como posso eu harmonizar todas estas ocupações? Falta-me tempo para tudo, é verdade. Mas o que devo fazer? Desistir dos meus sonhos? Quando o trabalho me aperta e as energias se esgotam, por vezes perco o ânimo, sim. Mas é nesses momentos que sinto uma mensagem dentro do peito reclamando uma publicação urgente. Também sinto que quando escrevo uma nova vida me invade. Viajo embalada na emoção do mundo que construo no pedaço de papel. A escrita consola-me, estimula-me, é a herança mais bela que Deus me legou, não, não posso desistir.

No fim da jornada de oito horas de trabalho regresso ao lar, muitas vezes exausta. Cuido da casa, da cozinha e das crianças. Quando todos dormem é que escrevo porque necessito de tranquilidade e silêncio. Consigo conciliar estas actividades porque imponho sobre mim uma disciplina religiosa. Mas por vezes falho. Nos momentos de criação literária alguns trabalhos ficam por fazer; a casa é mal arrumada e a comida fica à pressa. Não são poucas as vezes que a família reclama um pouco mais de atenção. Por vezes nem tenho tempo de cuidar da minha aparência e apareço na rua com um aspecto desastroso. Há momentos em que o trabalho me esgota tanto que na manhã seguinte tenho dificuldade em despertar. Chego tarde ao emprego com muita frequência, com os olhos avermelhados pelo trabalho nocturno. Alguns colegas chegaram a pensar que passava as noites em vícios e orgias. Mas isso foi ultrapassado. Eles entendem-me.

A escrita trouxe-me uma série de conflitos na esfera familiar. Raros são os casos de mulheres que seguem a carreira artística e que possuem uma família equilibrada. Esta é a minha situação e a minha luta. Com as minhas mãos, afasto pouco a pouco os obstáculos que me cercam e construo um novo caminho na esperança de que, num futuro não muito distante, as mulheres conquistarão maior compreensão e liberdade para a realização dos seus desejos. Devo dizer que não há nada de heroico na minha luta e, de resto, desfruto de todo o prazer que a escrita me proporciona.

Em Moçambique há uma guerra. A cidade da Matola onde eu vivo é alvo de confrontos entre as tropas governamentais e os rebeldes. Os estrondos das bombas fazem já parte do nosso ambiente nocturno. Vezes sem conta as balas estilhaçam os vidros da minha janela. Em cada noite a insegurança é absoluta. Na hora de dormir, a despedida, o desejo de uma boa noite tem um sentido verdadeiro, porque o novo amanhecer poderá não pertencer mais à nossa história. Por isso mesmo dou aos meus escritos um carácter de urgência. Não gostaria de morrer sem ter concluído a minha obra. Várias vezes fui obrigada a abandonar a inspiração porque na minha rua morriam homens em combate. Várias vezes abandonamos a casa interrompendo os meus escritos porque tinha que procurar abrigo, a guerra era quente. Vezes sem conta vi-me na obrigação de despertar a altas horas da madrugada e retomar o trabalho porque a essa hora é que os combates cessam. 
Escrevi a minha primeira obra debaixo de estrondos e ameaças de morte. Publiquei-a. escrevi a segunda debaixo do mesmo ambiente. Está no prelo. Trabalhar numa atmosfera de morte é minha forma de resistir. Ninguém tem o direito de interromper os meus sonhos.

Mesmo que a maldita guerra não termine, se a morte não me ceifar, escreverei o terceiro.

Depois de todas estas actividades, há uma interrogação que paira na minha mente: será que escrevendo cada dia mais livros, estou a contribuir para o desenvolvimento da mulher e da sociedade? Às vezes penso que não. Às vezes penso que sim. Porque em primeiro lugar, escrevendo realizo a minha ambição, o meu ego. Sinto que escrever livro não é tudo quanto basta. Sinto que a maior contribuição virá no dia em que conseguir lançar, na terra fértil, a semente da coragem e da vontade de vencer nos corações das mulheres que pertencem à geração do sofrimento. A minha maior realização virá no memento em que a planta brotar, no momento de vê-la crescer. Mesmo antes de vê-la florir, poderei já retirar-me da luta, repousar na sombra mais próxima, em paz e tranquilidade.

\section{NOTAS}

1 Testemunho escrito em 1992 e publicado em meados de 1994, por iniciativa da UNESCO em fase dos preparativos da Conferência Internacional sobre a Mulher, Paz e Desenvolvimento, realizada em Pequim em 1995. Texto inédito no Brasil, devidamente autorizado pela autora para integrar esta edição da Revista Abril.

2 Escritora moçambicana e membro da AEMO - Associação dos Escritores Moçambicanos.

Recebido para publicação em 15/10/2012

Aprovado em 28/01/2013 